\title{
The environmental impact of refuse derived fuel co-combustion with lignite
}

\author{
Piotr Krawczyk ${ }^{1, *}$, Krzysztof Badyda ${ }^{1}$, and Aleksandra Mikołajczak $^{1}$ \\ ${ }^{1}$ Institute of Heat Engineering, Warsaw University of Technology, 21/25 Nowowiejska Street, 00—665 Warsaw, Poland
}

\begin{abstract}
Legal regulations on waste disposal require waste producers to limit landfilling and to find different ways of waste management, the preferred methods being recycling of material and energy potential. Currently, in Poland, the only consumers of refuse-derived fuels (RDF) are cement plants. However, their ability to utilize alternative fuel is far from the estimated potential. One solution would be to redirect the excess fuel to power and heat production facilities. Unfortunately, these sectors are facing a number of problems related to the thermal treatment of waste, mainly formal nature. Co-combustion of waste in power plants raises a lot of concern among their employees and local communities. Especially significant is the harmfulness of usage of fuel from waste for the people's lives or health, or the environment. The article compares the environmental footprints of the combustion process of: waste - based fuel (RDF) and lignite. The analysis was performed for a standard pulverized coal fired boiler. Comparative assessment was made by analyzing the total environmental impact of all combustion products of the two fuels. Final results have shown, that the environmental footprint of waste-based fuels can be similar or even smaller than traditional coal-based fuels.
\end{abstract}

\section{Introduction}

The issue of the waste to energy use is a current and extremely important issue from the implementation of sustainable development policy point of view. This challenge is particularly valid while referring to Refuse Delivered Fuel (RDF).

Like presented in [1], the potential of waste-based fuel production in Poland equals to 4,5-6 m. t/year. In Poland, in point of fact the only recipient of Refuse Derived Fuel (RDF) are cement plants. In the power plants and combined heat and power plants, the RDF is not used. The obstacle is formal and legal requirements established for the process of incineration / coincineration of waste, emission of pollutants and the possibility of adverse changes in ash parameters.

It is estimated that Polish cement plants use approx. $1,000,000 \mathrm{Mg}$ of waste-based fuels per year and can increase this amount by approx. 400,000 $\mathrm{Mg}$ [2, 3]. Possibilities for co-combustion of waste in this sector are limited. Cement plants will not be able to manage all the waste-based fuels produced in the country.

It is worth to mention, that the cement production peak occur in the summer, which causes the significant RDF demand reduction in the winter, when the cement plants work with the partial loads.

Basing on the facts presented above it can be claimed, that the part of the RDF producers will not be able to sell all produced waste-based fuel, unless the possibility of its use in the other sectors, like heat and/or power generation will be created
The energy use of waste would be possible to spread if the waste-based fuel could not have the waste status. However, the question arises whether it is possible to create such a fuel and carry out the procedure of losing the status of waste.

The conditions that have to be met in order to make the waste lost its status of waste and thus become a fuel are crucial. In legal acts [4], in addition to several technical, economic and technological conditions, the environmental condition can be found. Due to that the re-use of the object or waste substance should not lead to adverse effects on life, human health or the environment. A literal confirmation of no harmfulness of fuel from waste is impossible. It is due to the fact that at the present moment, substances whose incineration "does not lead to negative effects on life, human health or the environment", even to a minimal extent, are not known. It should be emphasized that this applies not only to fuels from waste but also to any other currently used fuel. Therefore, it is necessary to determine the threshold of environmental nuisance at which we "consider" the fuel to be harmless to the environment. Such a point can be defined as, for example the ecological impact of the lignite burning.

In the other words, it can be assumed that in order to waste fuel to be deprived of the waste status it must meet environmental criteria, including indicators of environmental nuisance for human health and life determined by, for example lignite, which is after all allowed for the combustion as fuel.

\footnotetext{
* Corresponding author: piotr.krawczyk@itc.pw.edu.pl
} 
The article presents own results of the elemental composition of wastes mixture investigation. The compounds were generated by being sorted from the over-sieve part of municipal waste unwanted substances from the fuel point of view, i.e. multi-material waste, ferrous and non-ferrous metals, non-flammable fractions (ash). Marked waste samples were prepared on a typical sorting line of municipal waste equipped with, among the others three optosegregators. The used sorting line is located in one of the Polish cities. The obtained results were used to assess the relative environmental nuisance of the mixture of waste used as fuel in comparison with lignite.

\section{Characteristics of the compared fuels}

The subjects to the analysis were: lignite and wastebased fuel. Technical parameters and elementary composition of the analyzed fuels are presented in Table 1.

Table 1. Results of elementary and technical analysis of analyzed fuels

\begin{tabular}{|c|c|c|c|}
\hline Parameter & Unit & Lignite & $\begin{array}{c}\text { Waste- } \\
\text { based fuel }\end{array}$ \\
\hline Total humidity & $\%$ & 54.8 & 16.74 \\
\hline Volatile parts content & $\%$ & 37.065 & 73.47 \\
\hline Higher Heating Value & $\mathrm{J} / \mathrm{g}$ & 17308 & - \\
\hline Lower heating value & $\mathrm{J} / \mathrm{g}$ & 7274.5 & 19009.6 \\
\hline Analytical humidity & $\%$ & 14.9 & 2.99 \\
\hline Ash content & $\%$ & 10.35 & 13.39 \\
\hline Carbon content & $\%$ & 45.8 & 52.74 \\
\hline Hydrogen content & $\%$ & 3.465 & 6.63 \\
\hline Total sulphur content & $\%$ & 1.545 & 0.11 \\
\hline Nitrogen content & $\%$ & 0.515 & 0.65 \\
\hline Chlorine content & $\%$ & 0.0135 & 0.99 \\
\hline Fluorine content & $\%$ & 0.06 & 0.0094 \\
\hline $\begin{array}{c}\text { Sum of } 9 \text { heavy } \\
\text { metals }\end{array}$ & $\mathrm{mg} / \mathrm{kg}$ d.m. & 224.3 & 261.2 \\
\hline Thallium & $\mathrm{mg} / \mathrm{kg}$ d.m. & 0.1 & 0.1 \\
\hline Cadmium & $\mathrm{mg} / \mathrm{kg} \mathrm{d.m.}$ & 0.6 & 0.27 \\
\hline Mercury & $\mathrm{mg} / \mathrm{kg} \mathrm{d.m.}$ & 0.416 & 0.35 \\
\hline
\end{tabular}

The lignite with a chemical composition similar to the one presented in the table is mined in one of the Polish mines and used in the pulverized boilers.

The analyzed waste-based fuel was obtained on the standard MBP line of municipal waste segregation [5 7]. The substrate for the fuel production consists of municipal waste coming from the county town. During the installation work the so-called composite materials that were suspected of carrying heavy metals were tried to being get rid of. The analyzed fuel consisted mainly of four waste material fractions: plastics, waste paper, wood and textile materials in ratios resulting from their natural content in the tested waste stream.

\section{Methodology of the fuel environmental harmfulness assessment}

The environmental harmfulness of the given fuel combustion is the sum of the environmental harmfulness of all products of this process. It may be considered as the influence of a given substance on, among the others, environmental pollution, toxicity to living organisms and greenhouse effect [ 8 -13].

The properties of fuels significantly effect on the emission of harmful substances into the environment. These properties can be generally divided into two groups. The first group includes parameters affecting the technical suitability of the fuel for combustion: calorific value, moisture content, ash and combustible substances content and volatile parts. The second group consist of the chemical composition of the fuel and in particular the content of such harmful substances as sulfur, chlorine, fluorine and heavy metals. In addition to the harmful substances in the fuel, the emission in the exhaust gases depends on some combustion parameters such as: temperature distribution, boiler flue gas residence time, etc. Combustion products particularly sensitive to the process parameters are incomplete combustion products (i.e. CO) and nitrogen oxides.

The comparison of the particular fuels or the industrial installations operation due to their impact on the natural environment usually presents many difficulties. This is due to the need to take into account the specificity of both individual components and technological processes. Descriptions of the methods for assessing the environmental impact of combustion installations are available in the literature. According to the approach proposed in [14], the entire combustion process should be analyzed comprehensively to determine appropriate indicators of nuisance for each possible combustion product. The total burden of all combustion products is then the sum of individual nuisances.

The indicator of the nuisance for the environment of the substance generated in the combustion process related to the unit of energy produced includes, among the others:

- calorific value of fuel;

- efficiency of the exhaust gases cleaning system (for each given components);

- coefficient of formation of a given component in the combustion chamber $[\mathrm{kg} / \mathrm{kg}$ of fuel $]$;

- the relative nuisance of a given component contained in the exhaust gas.

Table 2. Relative nuisance (toxicity) of the exhaust gases components [15].

\begin{tabular}{|c|c|}
\hline Component & $\begin{array}{c}\text { Value of toxicity } \\
\text { coefficients }\end{array}$ \\
\hline $\mathrm{CO}$ & 1 \\
\hline $\mathrm{Ash}$ & 5 \\
\hline $\mathrm{TOC}$ & 5 \\
\hline $\mathrm{HF}$ & 50 \\
\hline $\mathrm{SO}_{2}$ & 1 \\
\hline $\mathrm{NO}$ & 0,25 \\
\hline $\mathrm{HCl}$ & 5 \\
\hline $\mathrm{Cd}, \mathrm{Tl}, \mathrm{Hg}$ & 1000 \\
\hline $\mathrm{Sb}, \mathrm{As}, \mathrm{Pb}, \mathrm{Cr}, \mathrm{Co}, \mathrm{Cu}, \mathrm{Mn}, \mathrm{Ni}$, & 100 \\
\hline
\end{tabular}

The relative nuisance of the given components contained in the exhaust depends on the type of substance and is usually related to the toxicity of the selected component, 
e.g. $\mathrm{SO}_{2}$. Their values based on [15] are presented in Table 2.

The total nuisance indicator, which can be calculated as the sum of nuisance indicators for individual substances arising in the combustion process, may be the basis for an objective comparison of the harmfulness of fuels. It takes into account not only the specificity of all components and their harmfulness, but also individual features of the installation.

According to the presented approach, when comparing ecological harmfulness of two fuels burned in the same installation, it is necessary to determine the same indicators characterizing the combustion installation, efficiency of exhaust gas cleaning etc. This way the result of the comparison does not depend on the characteristics of the combustion plant itself, and only indicators related to the physical and chemical properties of the fuel are concerned. In this situation, the individual environmental index of the substance "i" can be defined as:

where:

$$
\mathrm{JWU}_{\mathrm{i}}=\mathrm{Z}_{\mathrm{i}} \cdot \mathrm{W}_{\mathrm{K}} \cdot \mathrm{t}_{\mathrm{sp} \mathrm{i}}
$$

$\mathrm{Z}_{\mathrm{i}}$ - component ,i” content in the fuel (ash, sulphur, nitrogen, chlorine, fluorine, heavy metals) $[\mathrm{mg} / \mathrm{MJ}]$;

$\mathrm{W}_{\mathrm{Ki}}$ - conversion ratio of component "i" in the fuel to the harmful component in the exhaust gases - taking into account the existing purification system [\%]

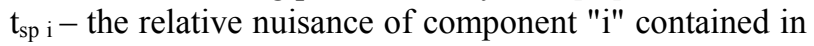
the exhaust gases $\left[\mathrm{kg} \mathrm{SO}_{2} / \mathrm{kg}\right.$ i]

The total nuisance rate of a given fuel is the sum of individual harmfulness of its components and can be expressed as:

$$
\mathrm{CWU}=\sum \mathrm{Z}_{\mathrm{i}} \cdot \mathrm{W}_{\mathrm{K}} \cdot \mathrm{t}_{\mathrm{sp} \mathrm{i}}
$$

Based on the presented approach the environmental nuisance of the analyzed fuels were compared.

For the purpose of the introduced method of fuels comparison the content of the analyzed elements in the fuel should be expressed as the amount of a given substance contained in the fuel per unit of chemical energy of this fuel, i.e. mg/MJ. For the purpose of these analysis, it was assumed that concentrations of all elements should be related to the unit of chemical energy in the working condition of the fuel (table 3 ).

Table 3. Comparison of the content of individual elements in lignite and waste-based fuel per unit of chemical energy.

\begin{tabular}{|c|c|c|c|}
\hline Parameter & Sign & $\begin{array}{c}\text { Lignite - } \\
\text { working } \\
\text { condition } \\
{[\mathrm{mg} / \mathrm{MJ}]}\end{array}$ & $\begin{array}{c}\text { Waste- } \\
\text { based fuel } \\
- \text { working } \\
\text { condition } \\
{[\mathrm{mg} / \mathrm{MJ}]}\end{array}$ \\
\hline Ash content & & 13392 & 6044 \\
\hline $\begin{array}{c}\text { Total sulphur } \\
\text { content }\end{array}$ & $\mathrm{St}$ & 1090,06 & 49.66 \\
\hline Nitrogen content & $\mathrm{N}$ & 363.35 & 293.47 \\
\hline Chlorine content & $\mathrm{Cl}$ & 9.53 & 446.97 \\
\hline Fluorine content & $\mathrm{F}$ & 42.33 & 4.24 \\
\hline $\begin{array}{c}\text { 9 heavy metals } \\
\text { total amount }\end{array}$ & & 10.225 & 11.441 \\
\hline Thallium & $\mathrm{Tl}$ & 0.006 & 0.004 \\
\hline Cadmium & $\mathrm{Cd}$ & 0.030 & 0.012 \\
\hline Mercury & $\mathrm{Hg}$ & 0.023 & 0.015 \\
\hline
\end{tabular}

Analyzing the data presented in the Table 3, it can be concluded that fuel from waste in relation to lignite is characterized by, among the others:

- lower ash content;

- lower sulfur content;

- lower nitrogen content;

- significantly higher chlorine content;

- lower content of fluorine;

- comparable content of the sum of "9" heavy metals (arsenic, lead, manganese, copper, chromium, nickel, vanadium, antimony, cobalt);

\subsection{The conversion rates determination}

As mentioned before, in order to determine the harmfulness (toxicity) of waste-based fuel in comparison with lignite, the total nuisance rate of the combustion process as defined above (equation 2) was used. The following fuel components were selected for the comparative analysis: ash, sulfur, nitrogen, chlorine, fluorine and heavy metals.

In the proposed approach, it was necessary to define the conversion factors of a given component in the fuel to the harmful component in the exhaust gases- taking into account the existing treatment system. In order to define them, the following data were used:

- for sulfur, nitrogen, chlorine, fluorine and ash - the measurements from one of the Polish lignite power plants;

- for heavy metals, including mercury - literature data [16].

The conversion rate determines what percentage of the weight of the component contained in the fuel (e.g. S) is converted to a harmful substance in the exhaust gases (e.g. $\mathrm{SO}_{2}$ ) and passes through the exhaust clean-up system to the environment.

The conversion ratio for sulfur to sulfur dioxide emitted to the atmosphere was assumed at the level of $10 \%$. This means that about $10 \%$ of the sulfur content introduced into the boiler with the fuel goes to the environment in the form of $\mathrm{SO}_{2}$.

As a result of balancing the relevant components (elements) in the coal and flue-gases based on an actual data from the power plant, the following values of conversion rates were obtained:

$\cdot$ ash $\rightarrow$ dust $=0,022[\%]$;

$\cdot \mathrm{N} \rightarrow \mathrm{NOx}=17,22[\%]$

$\cdot \mathrm{Cl} \rightarrow \mathrm{HCl}=11[\%]$

$\bullet \mathrm{F} \rightarrow \mathrm{HF}=3[\%]$.

The values of the $\mathrm{N} \rightarrow \mathrm{NO}_{\mathrm{x}}$ conversion coefficient determined in the literature [17] for coal combustion takes values at the range of $12-20 \%$.

To estimate the conversion rates for heavy metals, the mass balance of heavy metals were determined in the coal power plant system equipped with an electrostatic precipitator and a wet flue gas desulphurisation unit according to the BREF [18]

According to these data, the majority of heavy metals are removed from the exhaust gases with dust separation in the electrostatic precipitator. The only exception is mercury, which is in gaseous form and passes into the 
environment in the amount of approx. $30 \%$ of its input mass introduced to the boiler.

Therefore, the following values of conversion ratios for heavy metals were assumed for the purposes of this assessment:

- The sum of "9" heavy metals - $0.1[\%]$;

- Thallium- $0.1[\%]$;

- Cadmium - 0.07 [\%];

- Mercury - $30.6[\%]$.

\section{Results}

Using the determined conversion coefficients, the total nuisance index (CWU) was calculated as the sum of individual harmfulness of the fuel components for lignite and waste-based fuel. The results are presented in the tables 4 and 5 .

Taking into account all the assumptions, the total environment nuisance indicator for the lignite equals to 216.2. For fuel from waste - 282.19. The comparison of both fuels shows that the harmfulness (nuisance) of waste-based fuel is about $30 \%$ higher than lignite (equation 3).

$$
\frac{C W U_{\text {waste-based fuel }}}{C W U_{\text {lignite }}}=\frac{282.19}{216.2}=1.3
$$

The analysis of the CWU structure for lignite indicates the sulphur and fluorine as the ones having the dominant role.

Table 4. The individual environmental index for lignite components and the total nuisance rate.

\begin{tabular}{|c|c|c|c|c|}
\hline & \multicolumn{2}{|c|}{$\begin{array}{c}\text { Conversion ratio } \\
{[\%]}\end{array}$} & $\begin{array}{l}\text { Relative nuisance } \\
\text { (toxicity) of the } \\
\text { exhaust gases } \\
\text { components [kg } \\
\mathrm{SO}_{2} / \mathrm{kg} \text { component] }\end{array}$ & $\begin{array}{c}\text { Lignite } \\
- \\
\text { JWU }\end{array}$ \\
\hline Dust & Ash $\rightarrow$ Dust & 0.022 & 5 & 14.73 \\
\hline Sulphur (S) & $\mathrm{S} \rightarrow \mathrm{SO}_{2}$ & 10 & 1 & 109.006 \\
\hline $\begin{array}{c}\text { Nitrogen } \\
\text { (N) }\end{array}$ & $\mathrm{N} \rightarrow \mathrm{NO}_{\mathrm{x}}$ & 17.22 & 0,25 & 15.64 \\
\hline $\begin{array}{c}\text { Chlorine } \\
\text { (Cl) }\end{array}$ & $\mathrm{Cl} \rightarrow \mathrm{HCl}$ & 11 & 5 & 5.4 \\
\hline Fluorine $(\mathrm{F})$ & $\mathrm{F} \rightarrow \mathrm{HF}$ & 3 & 50 & 63.49 \\
\hline $\begin{array}{c}9 \text { heavy } \\
\text { metals } \\
\text { total } \\
\text { amount }\end{array}$ & $\begin{array}{l}9 \text { heavy } \\
\text { metals } \\
\text { total } \\
\text { amount }\end{array}$ & 0.1 & 100 & 1.02 \\
\hline $\begin{array}{c}\text { Thallium } \\
\text { (Tl) }\end{array}$ & $\mathrm{Tl} \rightarrow \mathrm{Tl}$ & 0.1 & 1000 & 0.006 \\
\hline $\begin{array}{l}\text { Cadmium } \\
\text { (Cd) }\end{array}$ & $\mathrm{Cd} \rightarrow \mathrm{Cd}$ & 0.07 & 1000 & 0.021 \\
\hline $\begin{array}{c}\text { Mercury } \\
(\mathrm{Hg})\end{array}$ & $\mathrm{Hg} \rightarrow \mathrm{Hg}$ & 30.6 & 1000 & 7.038 \\
\hline CWU & & & & 216.20 \\
\hline
\end{tabular}

Table 5. The individual environmental index for wastebased fuel components and the total nuisance rate.

\begin{tabular}{|c|c|c|c|c|}
\hline & \multicolumn{2}{|c|}{ Conversion ratio $[\%]$} & $\begin{array}{c}\text { Relative } \\
\text { nuisance of } \\
\text { components } \\
{\left[\mathrm{kg} \mathrm{SO}_{2} / \mathrm{kg}\right.} \\
\text { component }]\end{array}$ & $\begin{array}{c}\text { Waste- } \\
\text { based fuel } \\
\text { - } \\
\text { JWU }\end{array}$ \\
\hline Dust & Ash $\rightarrow$ Dust & 0.022 & 5 & 6.64 \\
\hline $\begin{array}{c}\text { Sulphur } \\
\text { (S) }\end{array}$ & $\mathrm{S} \rightarrow \mathrm{SO}_{2}$ & 10 & 1 & 4.96 \\
\hline $\begin{array}{c}\text { Nitrogen } \\
\text { (N) }\end{array}$ & $\mathrm{N} \rightarrow \mathrm{NO}_{\mathrm{x}}$ & 17.22 & 0,25 & 12.63 \\
\hline $\begin{array}{c}\text { Chlorine } \\
\text { (Cl) }\end{array}$ & $\mathrm{Cl} \rightarrow \mathrm{HCl}$ & 11 & 5 & 245.83 \\
\hline $\begin{array}{c}\text { Fluorine } \\
\text { (F) }\end{array}$ & $\mathrm{F} \rightarrow \mathrm{HF}$ & 3 & 50 & 6.36 \\
\hline $\begin{array}{l}9 \text { heavy } \\
\text { metals } \\
\text { total } \\
\text { amount }\end{array}$ & $\begin{array}{l}9 \text { heavy } \\
\text { metals } \\
\text { total } \\
\text { amount }\end{array}$ & 0.1 & 100 & 1.14 \\
\hline $\begin{array}{c}\text { Thallium } \\
\text { (Tl) }\end{array}$ & $\mathrm{Tl} \rightarrow \mathrm{Tl}$ & 0.1 & 1000 & 0.004 \\
\hline $\begin{array}{c}\text { Cadmium } \\
\text { (Cd) }\end{array}$ & $\mathrm{Cd} \rightarrow \mathrm{Cd}$ & 0.07 & 1000 & 0.0084 \\
\hline $\begin{array}{c}\text { Mercury } \\
(\mathrm{Hg})\end{array}$ & $\mathrm{Hg} \rightarrow \mathrm{Hg}$ & 30.6 & 1000 & 4.59 \\
\hline CWU & & & & 282.19 \\
\hline
\end{tabular}

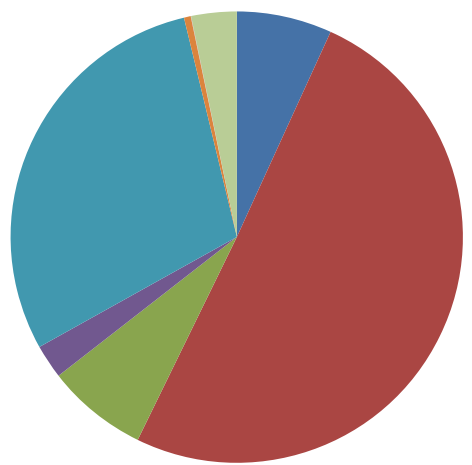

Fig. 1. The CWU structure for lignite.

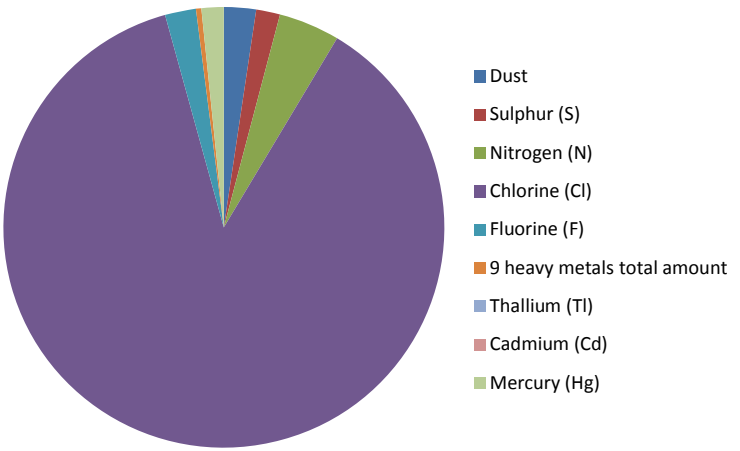

Fig. 2 The CWU structure for the waste-based fuel. 
Analyzing the results obtained for the waste-based fuel, it can be concluded that the chlorine plays the major role in the CWU structure (approximately 87\%).

During the preparation of the waste-based fuel at the sorting line, the optical separation was not used. This kind of segregation is implemented to remove PVC as the main carrier of chlorine in the waste. Hence the relatively high chlorine content in the analyzed wastebased fuel occur.

According to the results of the CWU comparison for lignite and waste-based fuel, reduction of chlorine content by approx. $30 \%$ in waste-based fuel (with unchanged other parameters), will result in equalization of both fuels indicators of nuisance. Basing on the authors experience, it can be concluded that applications of optical separation of PVC can lead to reduction of chlorine content in waste-based fuel by up to $70 \%$.

\section{Summary}

The authors research results justified that the environmental impact of the waste-based fuel combustion may be comparable with the traditional fossil fuels combustion in the installation with the set parameters (including the configuration of the exhaust gas treatment process). Therefore, the presented results may be an argument in the discussion on the possible loss of the waste status by the fuel produced on the basis of municipal waste. It means that, from the legal regulations point of view, the waste-based fuel fulfill the condition that the use of the object or substance does not lead to negative consequences for life, human health or the environment.

What's more, the technical equipment of modern waste sorting plants allows for deep and very conscious sorting of waste. According to the obtained results, the waste fuels should maximize the ratios of four fractions: waste paper, textiles, wood, plastics, excluding PVC.

The analyzes were carried out with the assumption of the invariance of the combustion process parameters in the boiler when using both fuels. This proposition can be considered as legitimate when using co-combustion of fuel from waste with primary fuel, i.e. lignite in limited quantities (several percent of the mass fraction of wastebased fuel). Examples of such practices can be found, among the others in German energy sector. The Jänschwalde power plant co-combusts waste-based fuel on the large-scale. In $2012,495,000 \mathrm{Mg}$ of RDF was coburned, which corresponds to $3.5 \%$ of the chemical energy of the fuel burned. Mostly used waste-based fuel is produced from mixed municipal waste.

Co-firing did not result in the reconstruction of the flue gas cleaning installation.

\section{References}

1. P. Krawczyk, J. Szczygieł, Rynek Energii, 6 (109), 6, (2013) (in Polish)

2. K. Badyda, P. Krawczyk, K. Pikoń, Energy, 100, 6, (2016)

3. M. Kalisz, The power of eco-business, 5, 6, (2013) (in Polish)

4. Directive 2008/98/EC of the European Parliament and of the Council of 19 November 2008 on waste and repealing certain directives (OJ L 312, 22.11.2008, pp. 3-30)

5. B. Bilitewski, G. Hardtle, K. Marek, Podręcznik Gospodarki Odpadami, (Seidel Przywecki, First edition, Warsaw 2003), (in Polish)

6. Polish Ministry of the Environment, Guidelines for the composting, fermentation as well as mechanical - biological waste treatment, 2008 (in Polish)

7. L. Sieja, Siła ekobiznesu, 7, 5, (2013) (in Polish)

8. K. Pikoń, K. Gaska, Polish Journal of Environmental Studies, 18 (3A), 11, (2009)

9. J. Guinée, Handbook on Life Cycle Assessment, Operational Guide to the ISO Standards, Ecoefficiency in industry and science, (Volume 7, Kluwer Academic Publishers, New York, Boston, Dordrecht, London, Moscow, 2004)

10. Á. Restrepo, R. Miyake, F. Kleveston, E. Bazzo, Energy, 45, 9, (2012)

11. K. Pikoń, Applied Energy, 75, 8, (2003)

12. K. Pikon, M. Bogacka, J. Nadziakiewicz, W. Stanek, L. Czarnowska, SGEM 2014 Conference Proceedings, 4 (1), 8, (2014)

13. EPA. Emissions From Waste Incineration. Good Practice Guidance and Uncertainty Management in National Greenhouse Gas Inventories

14. J. Nadziakiewicz, K. Pikoń, Paliwa z Odpadów 3, 5 (2001) (in Polish)

15. J. Niedziakiewicz, K. Wacławek, S. Stelmach, Procesy termiczne utylizacji odpadów, (Publisher of the Silesian University of Technology, 2012) (in Polish)

16. W. Kordylewski, Spalanie $i$ paliwa, (Wroclaw University of Technology Publishing House, 2008) (in Polish)

17. R. Sekret, Emisja substancji szkodliwych w procesie fluidalnego spalania mieszanki biomasy i węgla brunatnego. Częstochowa listopad 2008 (in Polish)

18. Reference documents under the IPPC Directive and the IED (Industrial Emissions Directive, 2010/75/EU) 